\title{
PERBEDAAN ANGKA RATA-RATA KARIES GIGI ANTARA MASYARAKAT BALI VEGETARIAN DAN NONVEGETARIAN DI DESA BASARANG JAYA KABUPATEN KAPUAS
}

\author{
Fahmi Said ${ }^{1}$, Ida Rahmawati ${ }^{2}$
}

\begin{abstract}
ABSTRAK
Perbedaan pola makan vegetarian dan nonvegetarian terletak pada ada tidaknya asupan makanan hewani dan proporsi asupan makanan nabati. Pola makan yang menyangkut jenis atau bahan makanan, selain dapat mempengaruhi kesehatan umum dapat pula mempengaruhi tingkat kebersihan gigi dan mulut, salah satunya adalah dapat mempercepat terjadinya proses gigi berlubang. Vegetarian adalah orang yang hanya mengkonsumsi produk nabati dan berpantang daging. Vegetarian yang berpantang daging harus mencukupi kebutuhan protein dari produk nabati seperti kacang-kacangan, buah, sayur kaya protein, kalsium, dan vitamin. Alasan agama atau spiritual mendorong berkembangnya pola makan vegetarian, salah satunya di kalangan umat beragama Buddha. Tujuan dari penelitian ini adalah untuk mengetahui perbedaan rata-rata angka karies gigi antara masyarakat Bali vegetarian dan nonvegetarian di Desa Basarang Jaya Kabupaten Kapuas. Manfaat Diharapkan dapat digunakan sebagai masukan dalam hal perencanaan program kesehatan gigi, khususnya masalah gigi berlubang.

Penelitian ini dilakukan di Desa Basarang Jaya Kabupaten Kapuas, jenis penelitian deskriptif analitik dengan pendekatan cross sectional, dimana variabel sebab akibat yang terjadi pada objek penelitian diukur untuk dikumpulkan secara simultan (dalam waktu yang bersamaan). Populasi penelitian berjumlah 1575 orang dengan sampel berjumlah 38 orang, 19 orang masyarakat Bali vegetarian dan 19 orang nonvegetarian.

Hasil penelitian menunjukkan angka rata-rata karies gigi mesyarakat Bali vegetarian sebesar 7,32, sedangkan angka rata-rata karies gigi masyarakat Bali nonvegetarian sebesar 5,47 pada equal variance assumed adalah 0,376 dengan probabilitas signifikansi $0,376>0,05$ sehingga tidak ada perbedaan angka rata-rata karies gigi masyarakat vegetarian dan nonvegetarian.

Berdasarkan penelitian disimpulkan bahwa tidak ada perbedaan yang signifikan angka rata-rata karies masyarakat Bali vegetarian dan nonvegetarian. Karies disebabkan oleh banyak faktor, seperti gigi, saliva, bakteri, substrat dan waktu, meskipun dengan pola makan vegetarian yang lebih banyak mengkonsumsi asupan makanan nabati dapat mengurangi kejadian karies namun bila mengabaikan faktor lain maka angka rata-rata kariespun tidak berbeda dengan yang pola makannya nonvegetarian.
\end{abstract}

Kata Kunci : Karies, Vegetarian, Nonvegetarian

\section{PENDAHULUAN}

Berdasarkan hasil Survey Kesehatan Rumah Tangga (SKRT) pada tahun 1995, penyakit gigi dan mulut yang umumnya banyak ditemukan pada masyarakat adalah karies gigi dan penyakit periodontal, yaitu 63 persen penduduk Indonesia menderita karies gigi aktif (kerusakan pada gigi yang belum ditangani). Masyarakat yang mengeluh sakit gigi datang berobat ke fasilitas kesehatan pelayanan kesehatan gigi sudah dalam keadaan terlambat, ini terlihat dari rata-rata 6,4 gigi yang rusak, 4,4 gigi sudah dicabut (Depkes RI, 2000).

Perbedaan pola makan vegetarian dan non vegetarian terletak pada ada 
tidaknya asupan makanan hewani dan proporsi asupan makanan nabati. Pola makan yang menyangkut jenis atau bahan makanan, selain dapat mempengaruhi kesehatan umum dapat pula mempengaruhi tingkat kebersihan gigi dan mulut, pada akhirnya dapat mempercepat terjadinya proses gigi berlubang ${ }^{1}$.

Vegetarian adalah orang yang hanya mengkonsumsi produk nabati dan berpantang daging. Vegetarian yang berpantang daging harus mencukupi kebutuhan protein dari produk nabati seperti kacang-kacangan, buah, sayur kaya protein, kalsium, dan vitamin. Alasan agama atau spiritual mendorong berkembangnya pola makan vegetarian, salah satunya di kalangan umat beragama Buddha ${ }^{1}$.

Sedangkan nonvegetarian mengikuti pola makan gizi seimbang yang terdiri dari padi-padian, sayur, lauk pauk (daging), buah, dan susu. Pola makan non vegetarian tidak membatasi konsumsi makanan hanya pada produk nabati, tetapi juga mengikutsertakan produk hewani ${ }^{2}$.

\section{BAHAN DAN METODE PENELITIAN}

1. Bahan

Alkohol 70\%, kapas, betadine, sabun cuci tangan, handuk kecil, alat diagnostik set, glass plastik, formulir pemeriksaan karies gigi

2. Metode

Penelitian yang digunakan adalah jenis penelitian yang bersifat deskriptif analitik. Penelitian ini diarahkan untuk menggambarkan dan menjelaskan suatu keadaan atau situasi. Pendekatan penelitian ini adalah cross sectional, dengan Uji-T. a. Distribusi Frekuensi Menurut Jenis Kelamin Masyarakat Bali Vegetarian di Desa Basarang Jaya Kabupaten Kapuas Kalimantan Tengah

\begin{tabular}{|c|c|c|c|}
\hline No & Jenis Kelamin & Jumlah & Prosentase \\
\hline 1. & Laki-laki & 8 & 42,1 \\
\hline 2. & Perempuan & 11 & 57,9 \\
\hline & Jumlah & 19 & 100 \\
\hline \multicolumn{4}{|c|}{ Sumber : Data Sekunder } \\
\hline & $\begin{array}{l}\text { Jumlah } \\
\text { kelamin } p \\
\text { yaitu } 57,9 \\
\text { berjumlah }\end{array}$ & $\begin{array}{l}\text { esponde } \\
\text { empuan } \\
\text { sedang } \\
1 \% \text {. }\end{array}$ & $\begin{array}{l}\text { berjenis } \\
\text { lebih besar } \\
\text { an laki-laki }\end{array}$ \\
\hline
\end{tabular}

b. Distribusi Frekuensi Menurut Jenis Kelamin Masyarakat Bali Non Vegetarian di Desa Basarang Jaya Kabupaten Kapuas Kalimantan Tengah

\begin{tabular}{clcc}
\hline No & Jenis Kelamin & Iumlah & Prosentase \\
\hline 1. & Laki-laki & 4 & 21,1 \\
\hline 2. & Perempuan & 15 & 78,9 \\
\hline & Jumlah & 19 & 100 \\
\hline
\end{tabular}

Sumber : Data Sekunder

Jumlah responden berjenis kelamin perempuan lebih besar yaitu $78,9 \%$ sedangkan laki-laki berjumlah $21,1 \%$.

2. Hasil Penelitian

a. Vegetarian

Data khusus didapat dari hasil pemeriksaan DMF-T yang dilakukan penelitian sebanyak 19 orang yang mengkonsumsi vegetarian.

Nilai Mean, Median, Modus Dan Standar Deviasi

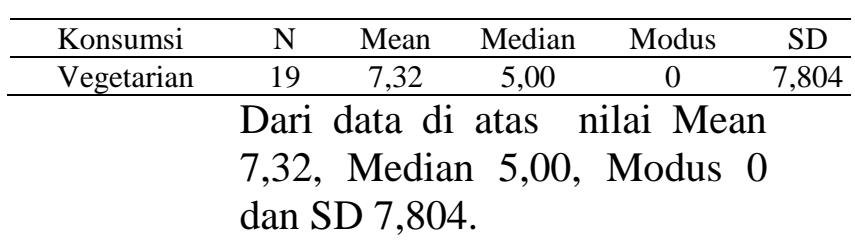

HASIL PENELITIAN

1. Data Umum b. Non Vegetarian 
Nilai Mean, Median, Modus

Dan Standar Deviasi

\begin{tabular}{lccccc}
\hline Konsumsi & N & Mean & Median & Modus & SD \\
\hline Non & 19 & 5,47 & 5,00 & 4 & 4,402 \\
Vegetarian & & & & & \\
\hline
\end{tabular}

Dari data di atas nilai Mean 5,47, Median 5,00, Modus 4 dan SD 4,402

c. Perbedaan Konsumsi Vegetarian dan Non Vegetarian

\begin{tabular}{|c|c|c|c|c|c|c|c|}
\hline \multirow[b]{3}{*}{$\begin{array}{l}\text { skor } \\
\text { plak }\end{array}$} & \multirow{3}{*}{$\begin{array}{l} \\
\text { Equal } \\
\text { variances } \\
\text { assumed }\end{array}$} & \multirow{2}{*}{\multicolumn{2}{|c|}{$\begin{array}{c}\text { F Sig. } \\
\text { Levene's Test } \\
\text { for Equality of } \\
\text { Variances }\end{array}$}} & \multirow[b]{2}{*}{$\mathrm{T}$} & \multirow[b]{2}{*}{$\mathrm{df}$} & \multirow[b]{2}{*}{$\begin{array}{l}\text { Sig. (2- } \\
\text { tailed) }\end{array}$} & \multirow[b]{2}{*}{$\begin{array}{c}\text { Mean } \\
\text { Difference }\end{array}$} \\
\hline & & & & & & & \\
\hline & & 3,086 & ,087 & 0,896 & 36 & ,376 & 1,842 \\
\hline & $\begin{array}{l}\text { Equal } \\
\text { variances not } \\
\text { assumed }\end{array}$ & & & 0,896 & $\begin{array}{c}28,40 \\
1\end{array}$ & ,378 & 1,842 \\
\hline
\end{tabular}

Sumber : Data Primer 
Hasil analisis uji beda pada rata-rata Konsumsi Vegetarian dan Nonvegetarian, dengan analisis Independent $t$ test, ditemukan mean different (selisih rata-rata) sebesar 1,842, $\mathrm{p}=0,087>0,05$ sehingga memakai varian sama (jadi yg dilihat sekarang uji t untuk varian sama equal) dari hasil diatas nilai $\mathrm{p}=0,376$ sehingga $\mathrm{p}>\propto$ 0,05 sehingga tidak ada perbedaan angka rata-rata karies gigi masyarakat bali Vegetarian dan Nonvegetarian Di Desa Basarang Jaya Kabupaten Kapuas Kalimantan Tengah.

\section{PEMBAHASAN PENELITIAN}

Berdasarkan distribusi frekuensi konsumsi vegetarian adalah nilai mean 7,32, median 5,00 modus 0 dan standar deviasi 7,804, sedangkan masyarakat konsumsi nonvegetarian nilai mean adalah 5,74, median 5,00, modus 4 dan standar deviasi 4,402. Hal ini menunjukkan bahwa rata-rata karies gigi masyarakat Bali vegetarian lebih tinggi daripada rata-rata karies gigi masyarakat Bali yang nonvegetarian.

Nilai pada equal variance assumed atau selisih rata-rata adalah 1,842 dengan probabilitas signifikansi $0,087>0,05$. Sehingga memakai varian yang sama (dengan uji t varian sama equal) dari hasil pada tabel 4.5 tersebut nilai $\mathrm{p}=0,376$ sehingga $p>\alpha \quad 0,05$ dapat disimpulkan bahwa tidak ada perbedaan angka rata-rata karies gigi antara masyarakat Bali vegetarian dan nonvegetarian di Desa Basarang Jaya Kabupaten Kapuas Kalimantan Tengah.

Tingkat kebersihan gigi dan mulut masyarakat vegetarian dan nonvegetarian berkaitan dengan pola makan (jenis dan frekuensi makan sehari-hari), kebiasaan membersihkan mulut setelah makan, dan tindakan pembersihan gigi dan mulut (frekuensi, waktu, dan lamanya penyikatan gigi). Pemilihan jenis makanan akan mempengaruhi kesehatan gigi dan mulut. Bahan makanan yang tergolong karbohidrat dapat difermentasikan oleh bakteri, sehingga dapat menurunkan $\mathrm{pH}$ plak dalam rongga mulut sampai dibawah 5 dalam waktu 1-3 menit. Hasil wawancara menunjukkan kelompok karbohidrat yang paling banyak dikonsumsi masyarakat vegetarian adalah nasi sebagai menu makan siang dan asupan karbohidrat pada vegetarian lebih tinggi daripada non vegetarian. Sumber utama karbohidrat di dalam makanan berasal dari tumbuh-tumbuhan dan hanya sedikit berasal dari hewani. Masyarakat non vegetarian pada umumnya mengkonsumsi makanan kaya karbohidrat, sayur-sayuran dan buahbuahan dengan proporsi yang lebih kecil daripada vegetarian (www.repository.usu.ac.id).

Kadar asupan nutrisi pada pola makan nonvegetarian juga berbeda dengan pola makan vegetarian. Menurut Barreto pada umumnya makanan-makanan dalam pola makan non vegetarian kaya akan protein dan lemak, namun rendah dalam kandungan serat dan karbohidrat. Sedangkan makanan dalam pola makan vegetarian kaya akan serat, karbohidrat, vitamin, dan mineral serta mampu mencukupi kebutuhan protein dan lemak (http://www.repository.usu.ac.id).

Pola makan vegetarian kaya akan makanan berserat. Brodribb, dkk melaporkan bahwa asupan serat pada vegetarian lebih tinggi daripada non vegetarian. Hal ini disebabkan karena serat terdapat pada seluruh komponen kuartet nabati, terutama sayur-sayuran dan buahbuahan. Serat selain memberikan keuntungan untuk kesehatan umum, juga bermanfaat untuk meningkatkan kebersihan gigi mulut (http://www.repository.usu.ac.id).

Makanan yang banyak mengandung air berarti sedikit mengandung karbohidrat dan sebaliknya. Makanan berserat seperti sayur-sayuran dan buah-buahan mengandung 75-95\% air. Sayur-sayuran dan 
buah-buahan merupakan pembersih alamiah pada permukaan oklusal gigi geligi, berkaitan dengan serat yang terkandung didalamnya. Serat dapat memperlambat proses makan, menghambat laju pencernaan makanan, dan meningkatkan intensitas pengunyahan. Proses mengunyah makanan berserat akan merangsang produksi air liur. Air liur dapat melindungi gigi dari proses kerusakan dan masyarakat vegetarian mengkonsumsi makanan berserat lebih tinggi daripada non vegetarian, oleh karena itulah tingkat kebersihan gigi dan mulut masyarakat vegetarian lebih baik daripada masyarakat non vegetarian.

Buah-buahan merupakan makanan berserat yang dapat mengendalikan pembentukan plak secara mekanis, karena proses pengunyahan secara langsung menimbulkan efek pembersih. Dari hasil wawancara diketahui bahwa masyarakat vegetarian lebih sering mengkonsumsi buahbuahan daripada masyarakat non vegetarian.

\section{KESIMPULAN}

Berdasarkan hasil penelitian angka rata-rata karies gigi masyarakat bali Vegetarian dan Non Vegetarian Di Desa Basarang Jaya Kabupaten Kapuas Kalimantan Tengah maka dapat diambil kesimpulan sebagai berikut :

1. Angka rata-rata karies gigi masyarakat Bali vegetarian di Desa Basarang Jaya Kabupaten Kapuas sebesar 7,32.

2. Angka rata-rata karies gigi masyarakat Bali nonvegetarian di Desa Basarang Jaya Kabupaten Kapuas sebesar 5,47.

3. Tidak ada perbedaan angka rata-rata karies gigi masyarakat bali Vegetarian dan Non Vegetarian Di Desa Basarang Jaya Kabupaten Kapuas Kalimantan Tengah.

\section{SARAN}

1. Diharapkan bagi masyarakat Bali vegetarian untuk mengurangi kejadian karies supaya mengurangi makanan yang banyak mengandung gula dan segera membersihkan giginya setelah makan, atau paling tidak berkumurkumur.

2. Diharapkan bagi masyarakat Bali vegetarian untuk memperbanyak mengkonsumsi buah-buahan yang banyak mengandung serat dan air, sehingga kejadian karies dapat dikurangi.

3. Masyarakat agar senantiasa memperhatikan kebersihan gigi dan mulutnya, segera membersihkan gigi setelah makan dan memeriksakan kesehatan gigi dan mulutnya minimal 6 bulan sekali walaupun tidak ada keluhan.

4. Diharapkan kepada instansi pelayanan kesehatan, khususnya kesehatan gigi untuk meningkatkan pengetahuan tentang kesehatan gigi masyarakat Desa Basarang Jaya misalnya dengan program penyuluhan (promotif) kesehatan gigi dan mulut.

\section{DAFTAR PUSTAKA}

1. Bangun, A, P., 2003, Vegetarian Pola Hidup Sehat Berpantang Daging, Agromedia Pustaka, Jakarta.

2. Yuliarti, N., 2008, Pilih Vegetarian atau Nonvegetarian? Plus Minus Pilihan Anda dari Segi Kesehatan, PT. Gramedia Pustaka Utama, Jakarta. 